Sharif University of Technology
Scientia Iranica
SCIENTIA
I RAN I CA

Research Note

\title{
Influence of diaphragm opening on seismic response of rectangular RC buildings with end shear walls
}

\author{
A.R. Khaloo, H. Masoomi*, S. Nozhati and M. Mohamadi Dehcheshmeh \\ Department of Civil Engineering, Sharif University of Technology, Tehran, Iran.
}

Received 2 February 2014; received in revised form 20 June 2015; accepted 28 November 2015

\section{KEYWORDS}

Floor diaphragm;

Reinforce concrete

structures;

Pushover curves;

In-plane flexibility;

Diaphragm opening.

\begin{abstract}
Routinely, behavior of floor diaphragms is assumed completely rigid in their plane, which leads to erroneous results in analysis and design of some particular buildings. In this study, 4-story RC buildings, with end shear walls and plan aspect ratio of 3 , are considered in order to investigate the influence of diaphragm openings on their seismic response. It is concluded that although in-plane floor flexibility has enormous effects on pre-yielding part of pushover curve, it has no influence on post-yielding part of that. Furthermore, the opening beside shear walls has crucial impact on response of building. Hence, it would be better off avoiding opening near the shear walls; if not, the in-plane flexibility of diaphragm has not to be overlooked even if the plan aspect ratio of building is 3 .

(C) 2016 Sharif University of Technology. All rights reserved.
\end{abstract}

\section{Introduction}

Modeling is one of the most important steps in analysis and design of structures. Most of the time, behavior of floor diaphragms is assumed completely rigid in their plane in order to simplify practical design. Although this assumption leads to acceptable results in analysis and design of conventional buildings, erroneous results may be assessed in some particular buildingsfor instance, narrow buildings with stiff end walls. Accordingly, behavior of the aforementioned buildings in future earthquakes will oppose the performances predicted in design phase and they are so vulnerable inasmuch as in-plane deflection of floor diaphragms is striking, which cannot be ignored. Unexpected building behaviors and even collapses, owing to neglected in-plane flexibility of diaphragm, were reported in several earthquakes during last decades. For instance,

\footnotetext{
Corresponding author. Tel.: +982166164211;

Fax: +98 912 1087rry

E-mail addresses: khaloo@sharif.ir (A.R. Khaloo);

masoomi.h@gmail.com (H. Masoomi);

saeed.nozhati@gmail.com (S. Nozhati);

mohamadi.dehcheshmeh@gmail.com (M.M. Dehcheshmeh)
}

during the 1994 Northridge earthquake, several parking structures suffered partial or complete collapse [13]. Large diaphragm in-plane deformations under earthquake loading are one reasonable cause of these failures. Diaphragms were assumed rigid in analysis and design of these parking structures. Since story drifts are much larger than those of shear walls due to significant flexibility of the diaphragms, distribution of seismic loads was strongly different from that which was anticipated. Therefore, gravity load system, which was not designed for lateral forces, experienced large displacement and failed, leading to the collapse of the parking structure.

According to ASCE7-10, reinforced concrete floor diaphragm in buildings with plan aspect ratio of 3:1 or less is assumed rigid [4]. This assumption neglects small diaphragm deformations; however, it is not accurate for cases in which the diaphragm deformations are large enough to highly affect building performance under seismic loading. In-plane diaphragm deformations are particularly significant in buildings such as the long and narrow ones and the ones with end shear walls; with setbacks in elevation; with plans in the shapes of letters L, Y, T, to name but a few [5-7]. Moeini and 
Rafezi $[8,9]$ investigated $\mathrm{RC}$ buildings with plans in different shapes by using response-spectrum dynamic analysis. Their study indicated that rigid diaphragm assumption is accurate enough in buildings without shear wall, even in asymmetric buildings. Nonetheless, this hypothesis leads to erroneous results in buildings with shear wall, especially buildings with end shear walls.

Al Harash et al. [10,11] studied influence of diaphragm openings on buildings with three types of floor diaphragm models, namely rigid, elastic, and inelastic. The results illustrate that interior frames absorb more shear when there are openings in diaphragm since in-plane diaphragm deformation is greater in this situation. Additionally, in these circumstances, rigid and elastic diaphragm models will result in an inaccurate estimation of the nonlinear seismic response of building inasmuch as these models overlook yielding in diaphragms. Thus, in long buildings with diaphragm openings, inelastic diaphragm model should be used in order to obtain precise results. They used models with lumped mass for each floor. However, assuming a lumped mass could be acceptable when we adopt rigid diaphragm in models. In this way, it seems that inelastic behavior of slabs in analyses of the models used in the aforementioned study comes from this assumption.

Therefore, in the current study, in order to investigate the flexibility of diaphragm, masses were distributed through the floor to show the real situation. As a simple supported beam has different responses under a single point load and a distributed load with the same magnitude, diaphragms would also be sensitive to applied load when they are modeled by real in-plane stiffness.

\section{Objectives}

The primary goals of the study presented here are to investigate the errors which appear in seismic parameters due to rigid diaphragm assumption and intensity of changes in these errors when there are openings in the diaphragm. The study attempts to accentuate the momentousness of diaphragm action on a specific class of buildings. This research considers buildings with plan aspect ratio of 3 and with end shear walls. Floor openings of different sizes are located in different parts of the plan in order to look into the influence of diaphragm opening on seismic response and pushover curves of such buildings.

\section{Description of models}

In this research, all models are 4-story reinforced concrete buildings with end shear walls. As shown in Figure 1, the plan of building structure is six bays $5 \mathrm{~m}$

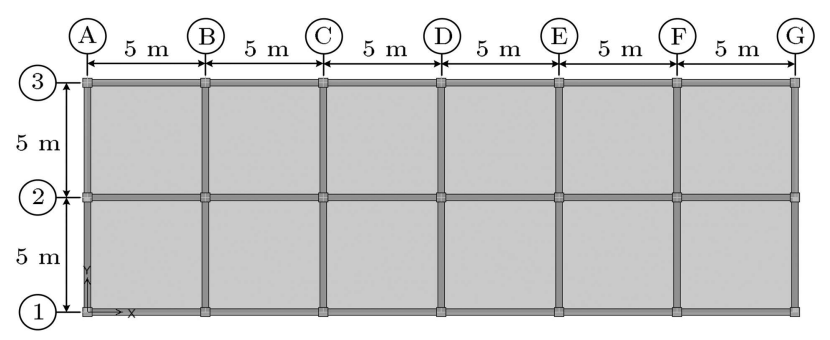

Figure 1. Plan of building without diaphragm opening (Model 4SEWNO).

in length and two bays $5 \mathrm{~m}$ in depth (i.e., plan aspect ratio of $3: 1$ ). Shear walls with $0.20 \mathrm{~m}$ of thickness are placed symmetrically at both ends, and each story has $3.50 \mathrm{~m}$ of height. All elements were designed and detailed to meet ACI318-99 [12] and UBC97 [13] prescribed forces. The lateral force resisting system in the $\mathrm{Y}$ direction consists of dual system and intermediate moment resisting frames (IMRF) are used in the $\mathrm{X}$ direction. The sizes of columns of the models are $0.45 \mathrm{~m}$ $\times 0.45 \mathrm{~m}$ and $0.40 \mathrm{~m} \times 0.40 \mathrm{~m}$ for $1-2$ stories and $3-4$ stories, respectively. The size of all beams is $0.30 \mathrm{~m} \times$ $0.40 \mathrm{~m}$ and the thickness of the floor slabs is $0.15 \mathrm{~m}$. For more details refer to [14].

In order to investigate influence of diaphragm opening, besides the model without opening that is shown in Figure 1, four models, which have $15 \%$ and $30 \%$ openings, are considered as shown in Figure 2.

\section{Numerical modeling}

Inelastic structural component models can be separated by the way that plasticity is distributed through the member cross sections and along column elements of its length [15]. The simplest models concentrate on the inelastic deformations at the end of the element. By concentrating on the plasticity in zerolength hinges with moment-rotation model parameters, these elements have relatively shortened numerically efficient formulations. The fiber formulation models allocate plasticity by numerical integrations through the member cross sections and along the member length. Uniaxial material models are defined to capture the nonlinear hysteretic axial stress-strain characteristics in the cross sections $[16,17]$.

Under large inelastic cyclic deformations, component strengths often deteriorate due to fracture, crushing, local buckling, bond slip, or other phenomena. If such degradations are included through appropriate modifiers to the stiffness and internal forces, the model can simulate most regular materials and devices experiencing hysteretic behavior $[18,19]$.

Nonlinear dynamic and static (pushover) analyses were carried out by using Perform-3D program [20]. General idealized relationships between the force and deformation of structural components in Figure 3 


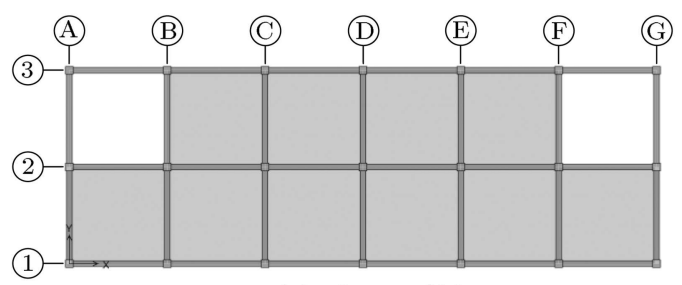

(a) $4 \mathrm{SEW} 15 \% \mathrm{O} 1$

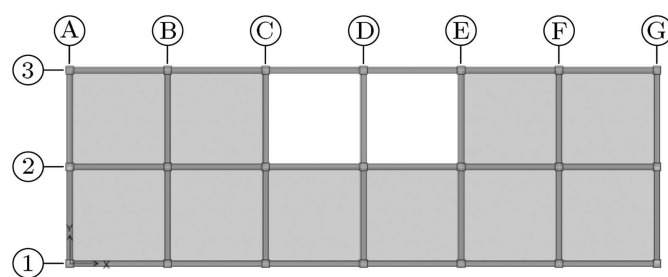

(c) $4 \mathrm{SEW} 15 \% \mathrm{O} 2$

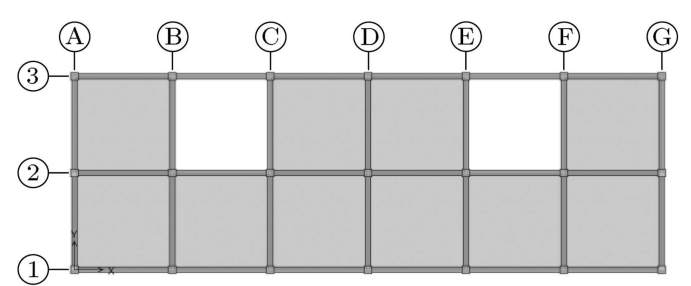

(b) $4 \mathrm{SEW} 15 \% \mathrm{O} 3$

Figure 2. Plan of buildings with $15 \%$ and $30 \%$ diaphragm openings.

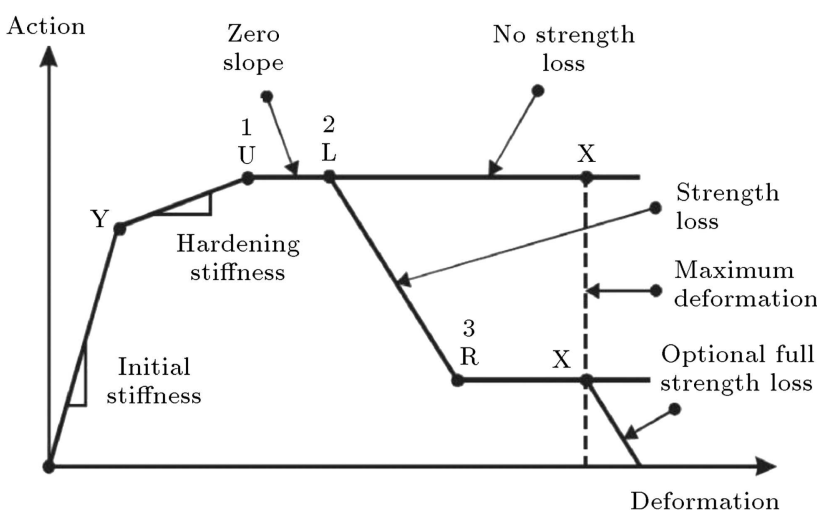

Figure 3. Generalized force-deformation relationship.

conform to the behavior model given in seismic rehabilitation guides such as FEMA 356 [21]. The important points, Y, U, L, R, and X, are, respectively, defined as the first yield point (where significant nonlinear behavior begins), the ultimate strength point (initiating point of perfect plasticity), the ductile limit point (initiating loss of strength), the residual strength point (initiating yielding after loss of strength), and point of deformation leading to final collapse [22].

\subsection{Modeling of beams}

Beams are composed of three types of components including a stiff end zone, an elastic beam element in the middle part, and a plastic hinge representing most of inelastic deformations, as shown in Figure 4. A plastic hinge has no length. FEMA 356 [21] explicitly mentions this type of model and gives deformation capacities. The stiffness in the joint region was assumed to be 10 times the stiffness of the middle part of the beam.

\subsection{Modeling of columns}

Columns are modeled in the same way as the beam, except that the plastic hinges have P-M-M interac-

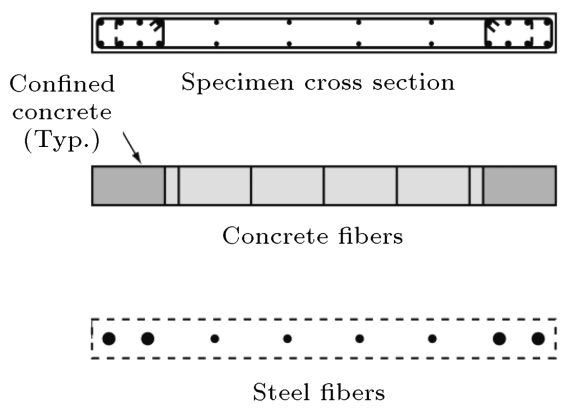

(a)
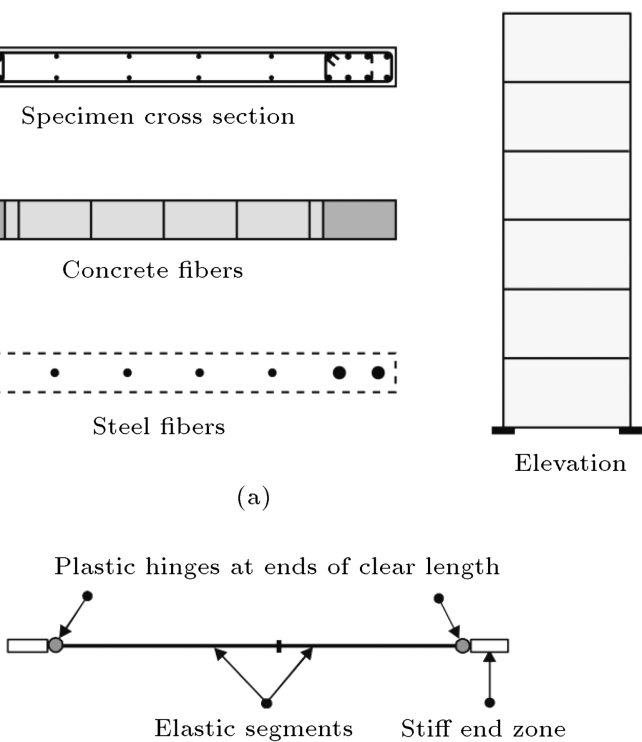

(b)

Figure 4. Nonlinear modeling of elements $[20,25,26]$ : (a) Fiber element representation of shear wall (slab); and (b) FEMA beam (column) model.

tion [20] and the end of column connected to the foundation is assumed to have no stiff end zone. The behavior of the plastic hinges is defined by the yield surface in Figure 5. This surface can be represented using three points [23], compressive yield point PC, tensile yield point $\mathrm{PT}$, and compressive strength and yield moment at balanced failure point $\mathrm{PB}$.

\subsection{Modeling of shear walls and slabs}

Nonlinear fiber elements representing the expected behavior of concrete and steel were used to model the shear wall and slab. A schematic cross section of the fiber element used to model shear wall and slab is shown in Figure 4. For the fiber concrete elements, only confined concrete was used with the expected strength, 

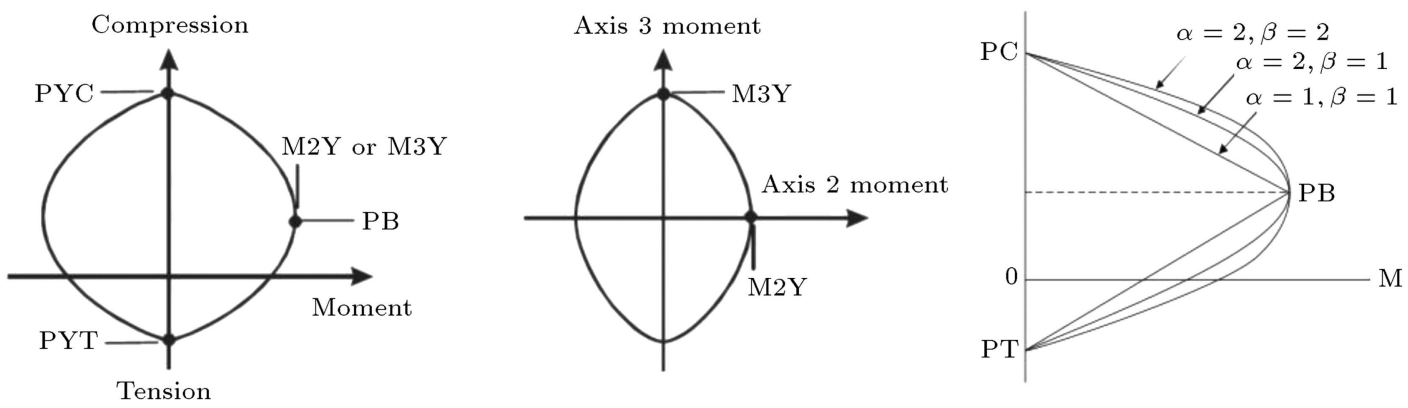

Figure 5. PMM yield surface for columns.

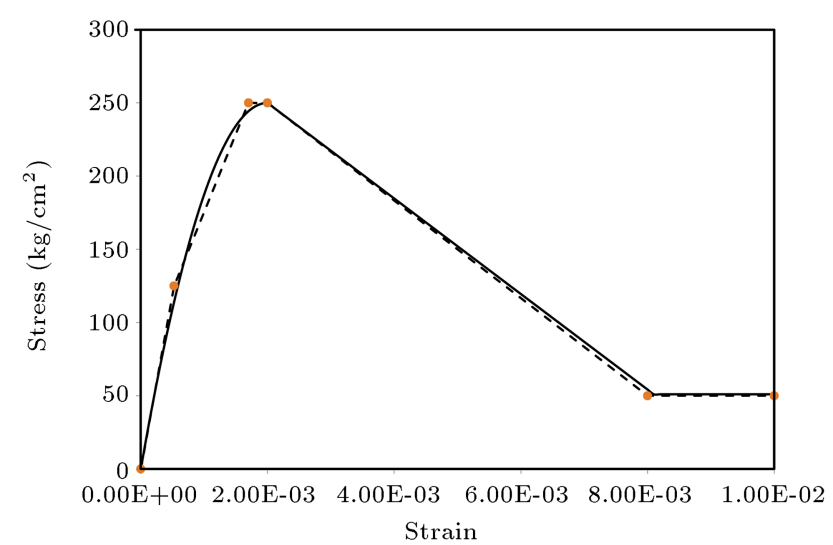

Figure 6. Concrete stress-strain relationship.

i.e. the unconfined concrete cover was neglected. The concrete stress-strain relationship was based on the modified Mander model for confined concrete [24], based on a nominal concrete compressive strength, $f_{c}^{\prime}$, of $25 \mathrm{MPa}$ and the tension strength of concrete was neglected (Figure 6). Since the used computer program, Perform-3D, requires the concrete stressstrain relation to be defined by four linear segments, four control points were selected to approximate the relation produced using the Mander model as shown in Figure 6. Both shear wall and floor slab were modeled nonlinearly in their plane, and they behave linearly out of plane [25].

\subsection{Cyclic degradation}

Cyclic energy dissipation factors are shown in Tables 1 and 2. Cyclic degradation of the reinforcing steel can be accounted for by specifying energy factors.

Table 1. Cyclic degradation of beams and columns.

\begin{tabular}{ccc}
\hline \multirow{2}{*}{ Points } & \multicolumn{2}{c}{ Energy factors } \\
\cline { 2 - 3 } & Beam & Column \\
\hline Y & 0.50 & 1 \\
U & 0.45 & 1 \\
L & 0.40 & 0.90 \\
R & 0.35 & 0.85 \\
X & 0.35 & 0.80 \\
\hline
\end{tabular}

Table 2. Cyclic degradation parameters of reinforcing steel.

\begin{tabular}{cc}
\hline Strain & Energy factor \\
\hline DY & 0.70 \\
0.0025 & 0.68 \\
0.0040 & 0.64 \\
0.0060 & 0.62 \\
DX & 0.60 \\
\hline
\end{tabular}

These factors alter the material backbone curve with each load cycle, making it dependent on the loading history. Perform-3D allows the user to define the relationship between the maximum strain in a given hysteresis loop and an associated energy factor. Energy factors represent the ratio of the area of the degraded hysteresis loop over the area of the un-degraded loop and are typically calibrated using test data. The energy factors used to model the reinforcing steel are the same as those used by Ghodsi and Ruiz [26].

\subsection{Beam-to-column connections}

From several experimental studies on seismic behavior of reinforced concrete beam-to-column connections, it was observed that if a deformable joint model was not defined in frame modeling, lateral drift of the structure was underestimated $[27,28]$. However, in this study, beam-to-column connections were neglected. In these circumstances, rigidity of diaphragm will be estimated conservatively, since considering beam-tocolumn connections causes more flexible lateral load resisting system; therefore, diaphragm would be more rigid in comparison to lateral load resisting system. Also, lateral displacements were compared in this study in the case of rigid diaphragm assumption and flexible diaphragm. Thus, since beam-to-column connections have approximately the same influence in both of these parameters, this negligence could be acceptable.

\section{Records selection}

In order to select suitable earthquake records for analysis, different codes have approximately the same 
recommendations. Regarding the number of accelerograms, Eurocode 8, FEMA 450 (2003 NEHRP recommended provisions), FEMA 356, and ASCE 7-05 recommend that a suite of not less than three motions should be used for time-history analysis. According to FEMA 356 Section 1.6.2.2, time-history analysis should not be performed with fewer than three data sets of ground motion time histories. Time histories should have magnitude, fault distances, and source mechanisms that are equivalent to those that control the design earthquake ground motion. For each data set, the Square Root of the Sum of the Squares (SRSS) of the 5\%-damped spectrum of the scaled horizontal components should be constructed. The data sets should be scaled such that the average value of the SRSS spectra does not fall below 1.4 times the 5\%-damped spectrum for the design earthquake for periods between $0.2 \mathrm{~T}$ seconds and $1.5 \mathrm{~T}$ seconds (where $\mathrm{T}$ is the fundamental period of the building) [29]. Where three time history data sets are used in the analysis of a structure, the maximum value of each response parameter (e.g., force in a member, displacement at a specific level) should be used to determine design acceptability. Where seven or more time history data sets are employed, the average value of each response parameter should be permitted to determine design acceptability.

In the current investigation, three pair records were selected and scaled. Therefore, a series of twenty two far-field quakes are selected from FEMA-p695 [30] for site class $\mathrm{C}$. The three records with the most fitness to the design response spectrum for site class $\mathrm{C}$ were selected; they are tabulated in Table 3. As shown in Figure 7, these three records were scaled for use in nonlinear analyses. The related scaled factors are also mentioned in Table 3 .

\section{Results and discussion}

Nonlinear dynamic and static analyses were conducted for each model; the results are discussed here.

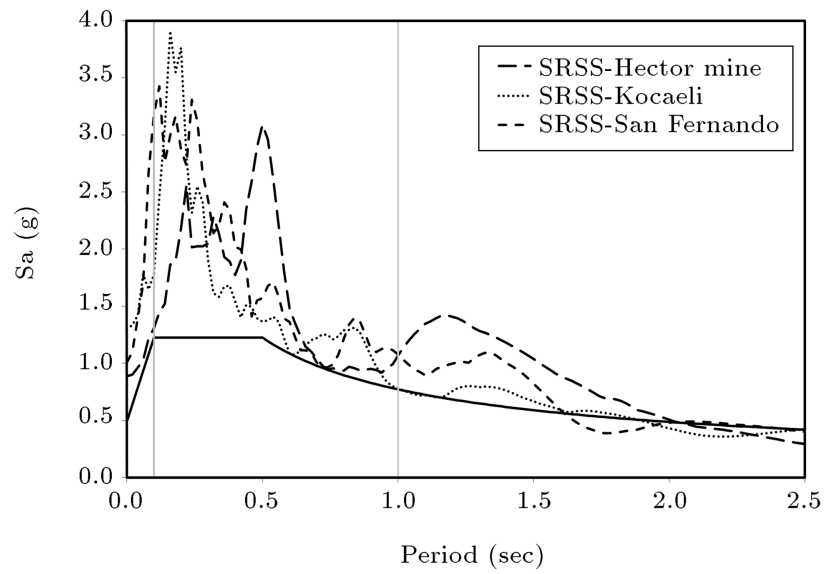

Figure 7. SRSS spectra were scaled to be greater than 1.4 times the design spectrum for the periods between $0.2 \mathrm{~T}$ and $1.5 \mathrm{~T}$.

\subsection{Pushover analysis}

Pushover analysis was conducted for all buildings and models were pushed by triangular distribution over the building height until the roof displacement met 1 percent of the building height (i.e. $0.15 \mathrm{~m}$ ). Pushover curves are illustrated in Figure 8 in two parts, namely rigid diaphragm and flexible diaphragm. As seen in Figure 8(a), if the rigid diaphragm assumption is used in the analysis, existence of opening in diaphragm will not affect pushover curves due to the fact that in-plane flexibility of diaphragm is not taken into account. In this situation, even if the opening is as large as $30 \%$ of all the diaphragm area, all buildings pushover curves will be virtually identical.

On the other hand, when in-plane flexibility of diaphragm is considered and diaphragm is modeled to perform in its nearly actual behavior, i.e. it can bend in its plane, an increase in diaphragm opening leads to decrease in in-plane stiffness of diaphragm, and thus it is expected that lateral displacement will be intensified. As indicated in Figure 8(b), the larger the opening in diaphragm, the greater the idealized yield displacement and the lower the effective lateral stiffness. Although the opening of model 4 SEW $30 \% \mathrm{O}$ is two times that of

Table 3. Selected records for time history analyses.

\begin{tabular}{|c|c|c|c|c|c|c|c|c|c|}
\hline \multirow{2}{*}{ No. } & \multicolumn{4}{|c|}{ Earthquake } & \multirow{2}{*}{ Component } & \multirow{2}{*}{$\begin{array}{l}\text { Duration } \\
\text { (sec) }\end{array}$} & \multirow{2}{*}{$\begin{array}{c}\text { PGA } \\
(\mathrm{g})\end{array}$} & \multirow{2}{*}{$\begin{array}{c}\text { Significant } \\
\text { duration (sec) }\end{array}$} & \multirow{2}{*}{$\begin{array}{l}\text { Scale } \\
\text { factor }\end{array}$} \\
\hline & $\mathbf{M}$ & Year & Name & Station & & & & & \\
\hline \multirow{2}{*}{1} & \multirow{2}{*}{7.1} & \multirow{2}{*}{1999} & \multirow{2}{*}{$\begin{array}{l}\text { Hector } \\
\text { Mine }\end{array}$} & \multirow{2}{*}{ Hector } & HEC000 & 45.3 & 0.266 & 11.65 & \multirow{2}{*}{0.697} \\
\hline & & & & & HEC090 & 45.3 & 0.337 & 9.66 & \\
\hline \multirow{2}{*}{2} & \multirow{2}{*}{7.5} & \multirow{2}{*}{1999} & \multirow{2}{*}{$\begin{array}{l}\text { Kocaeli, } \\
\text { Turkey }\end{array}$} & \multirow{2}{*}{ Arcelik } & ARC000 & 30 & 0.219 & 11.015 & \multirow{2}{*}{1.073} \\
\hline & & & & & ARC090 & 30 & 0.15 & 10.275 & \\
\hline \multirow{2}{*}{3} & \multirow{2}{*}{6.6} & \multirow{2}{*}{1971} & San & LA-Hollywood & PEL090 & 28 & 0.21 & 10.49 & \multirow{2}{*}{0.774} \\
\hline & & & Fernando & Stor & PEL180 & 28 & 0.174 & 11.16 & \\
\hline
\end{tabular}




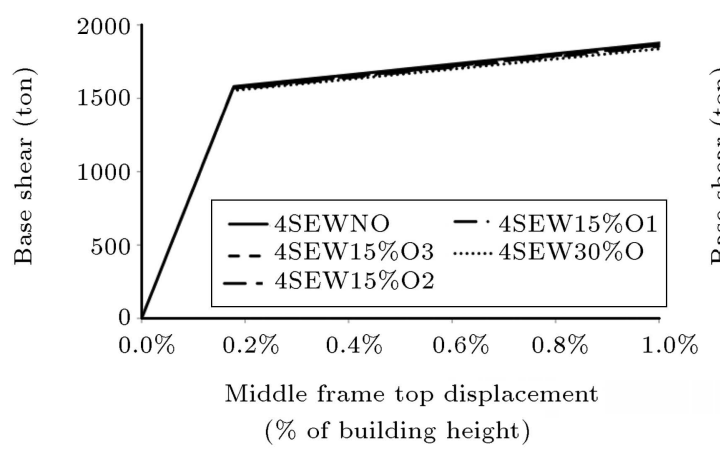

(a)

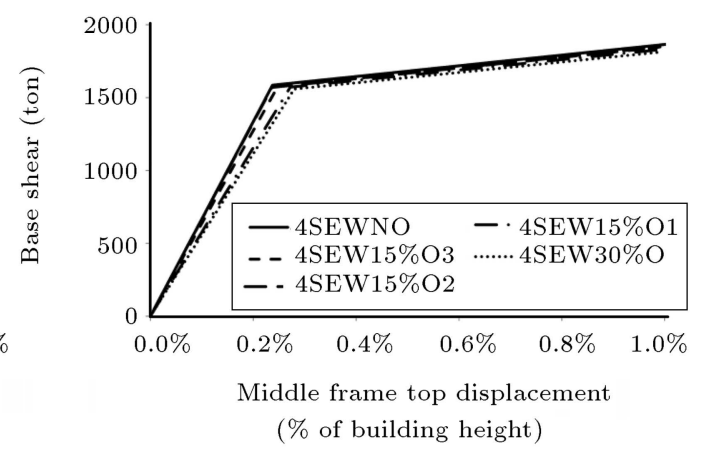

(b)

Figure 8. Buildings pushover curves with and without rigid diaphragm assumption: (a) Rigid diaphragm; and (b) flexible diaphragm.

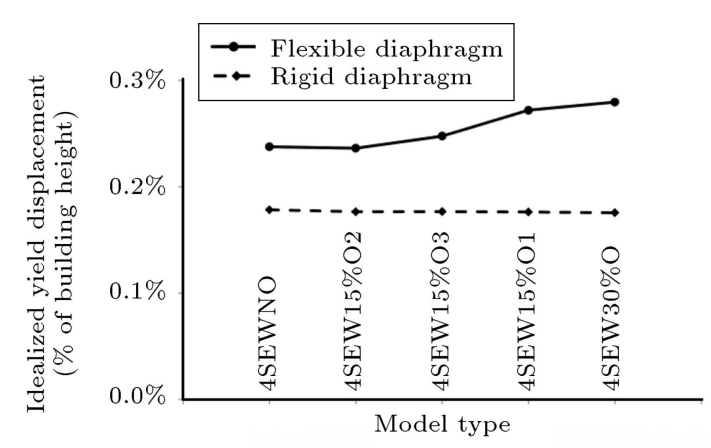

(a)

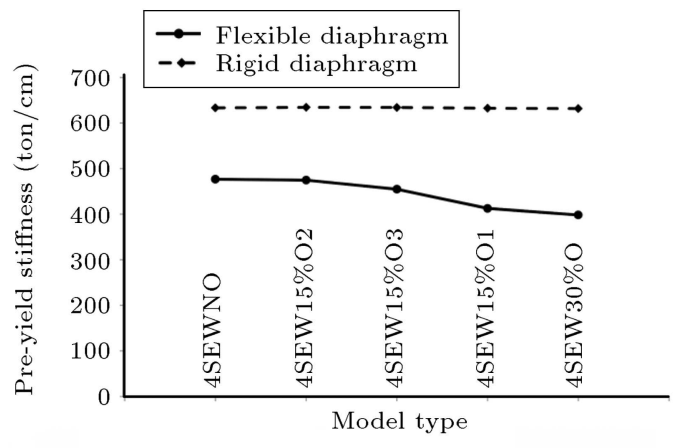

(b)

Figure 9. Variations of (a) idealized yield displacement, and (b) pre-yield stiffness by change in diaphragm openings in models with both rigid and flexible diaphragms.

model 4SEW15\%O1, in which the opening is located at both ends, near the shear walls, these two models have approximately similar pushover curves. In fact, besides the amount of opening, its location has a strong influence on response of building. Furthermore, model $4 \mathrm{SEW} 15 \% \mathrm{O} 2$, in which the opening is installed in the middle of the plan of the building, has a similar pushover curve to that of the model without opening (model 4SEWNO). It is concluded that diaphragm opening has greater influence when it is located near shear walls instead of the middle of building plan, which is the farthest location from shear walls.

The pre-yield parts of idealized pushover curves are different in models with flexible diaphragm and with rigid diaphragm. Considering the same displacement of middle frame in both flexible and rigid models, in the model with rigid diaphragm, all frames have identical displacements; however, displacement in middle frame is greater than those in other frames of the model with flexible diaphragm. Hence, the rigid diaphragm assumption forces the building to claim more base-shear in order to reach a certain displacement; in other words, the building responds in a stiffer manner. With this in mind, since yield base shear has the same value in both models with and without rigid diaphragm assumption, the building with rigid diaphragm reaches the yield base shear at lower displacement value. As shown in Figure 9, although idealized yield displacement and pre-yield stiffness have nothing to do with diaphragm opening in the condition of rigid diaphragm assumption, they will have different values by increase in opening of diaphragm in models with flexible diaphragm. Moreover, rigid diaphragm assumption gives rise to underestimation of idealized yield displacement and overestimation of pre-yield stiffness.

The post-yield parts of idealized pushover curves are virtually identical in all models whether with flexible diaphragm or with rigid diaphragm. From the pushover analysis, it is observed that in all buildings, shear walls are the first elements which yield and columns start yielding after the yielding of some beams. Nonetheless, all slab elements remain in elastic region until very large drift. In this regard, after the yielding point, decrease in stiffness of lateral load resisting system leads to much more increasing displacement rate, and in-plane deformation of diaphragm remains constant or decreases after shear walls yield. Thus, slabs respond in a stiffer manner than lateral load resisting system and their behavior approaches rigid diaphragm behavior. It is concluded that rigid diaphragm assumption or in-plane flexibility of floor 


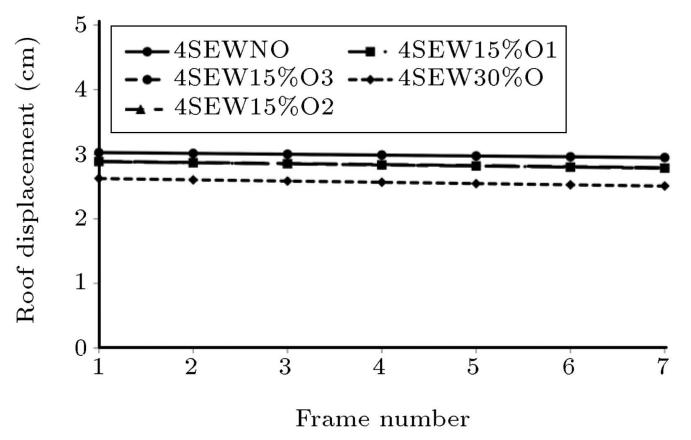

(a)

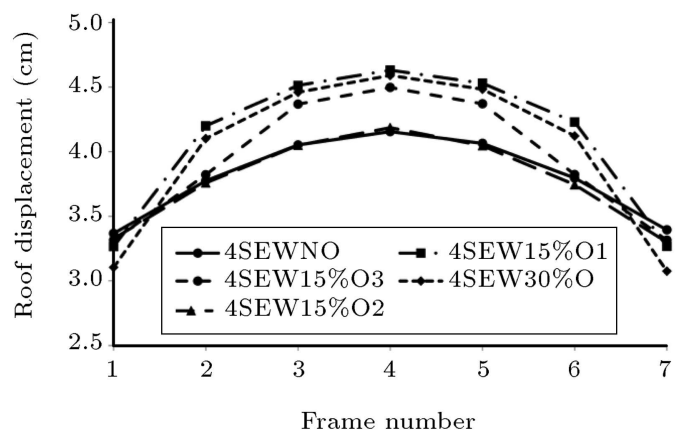

(b)

Figure 10. Variation of idealized yield base shear and post-yield stiffness by change in diaphragm openings in models with both (a) rigid diaphragm, and (b) flexible diaphragms.

Table 4. Pushover parameters in both flexible and rigid models, and the error resulting from rigid diaphragm assumption.

\begin{tabular}{|c|c|c|c|c|c|c|c|c|c|c|c|c|c|c|c|}
\hline \multirow[b]{2}{*}{ Parameter } & \multicolumn{3}{|c|}{ 4SEWNO } & \multicolumn{3}{|c|}{ 4SEW15\%O1 } & \multicolumn{3}{|c|}{ 4SEW15\%O2 } & \multicolumn{3}{|c|}{ 4SEW15\%O3 } & \multicolumn{3}{|c|}{ 4SEW30\%O } \\
\hline & Flex. & Rigid & $\begin{array}{c}\text { Err. } \\
\%\end{array}$ & Flex. & Rigid & $\begin{array}{c}\text { Err. } \\
\%\end{array}$ & Flex. & Rigid & $\begin{array}{c}\text { Err. } \\
\%\end{array}$ & Flex. & Rigid & $\begin{array}{c}\text { Err. } \\
\%\end{array}$ & Flex. & Rigid & $\begin{array}{c}\text { Err. } \\
\%\end{array}$ \\
\hline $\begin{array}{l}\text { Idealized yield } \\
\text { base shear }\left(V_{y}\right)\end{array}$ & 1585.4 & 1580.3 & 0.3 & 1571.7 & 1560.4 & 0.7 & 1569.9 & 1567.5 & 0.1 & 1576.3 & 1567.8 & 0.5 & 1558.5 & 1552.3 & 0.4 \\
\hline $\begin{array}{l}\text { Idealized yield } \\
\text { displacement }\left(\Delta_{y}\right)\end{array}$ & 0.0024 & 0.0018 & 25.0 & 0.0027 & 0.0018 & 35.2 & 0.0024 & 0.0018 & 25.3 & 0.0025 & 0.0018 & 28.7 & 0.0028 & 0.0018 & 37.2 \\
\hline $\begin{array}{l}\text { Pre-yield } \\
\text { stiffness }\end{array}$ & 476.6 & 633.1 & 32.8 & 412.7 & 632.4 & 53.2 & 474.7 & 634.3 & 33.6 & 454.7 & 634.1 & 39.4 & 398.2 & 631.6 & 58.6 \\
\hline $\begin{array}{l}\text { Post-yield } \\
\text { stiffness }\end{array}$ & 26.2 & 25.7 & 2.0 & 25.6 & 25.4 & 0.7 & 26.4 & 25.5 & 3.3 & 25.9 & 25.5 & 1.4 & 25.5 & 24.7 & 3.2 \\
\hline
\end{tabular}

diaphragm has no effect on post-yield part of pushover curve and, as indicated in Figure 10, idealized yield base shear and post-yield stiffness not only do not change models with different opening positions and sizes, but also have the same value in both rigid and flexible diaphragm models.

The summary of the pushover analysis results for all the cases is given in Table 4. Also, the errors of pushover results due to the rigid diaphragm assumption are calculated. As shown in the tables, idealized yield base shear and post-yield stiffness have the same value in flexible and rigid models. Moreover, it is clear that considering diaphragm as rigid causes high error in calculating idealized yield displacement and pre-yield stiffness. For instance, the errors of these parameters in model 4 SEW $30 \% \mathrm{O}$ are $37.2 \%$ and $58.6 \%$, respectively.

\subsection{Dynamic analysis}

Inelastic dynamic analyses were conducted for all buildings and seismic responses of buildings were studied. Maximum roof displacements of all models with and without rigid diaphragm assumption are illustrated in Figure 11. In models with flexible diaphragm, middle frames have greater displacement than that of the frames which include shear wall, while displacements are approximately equal for all frames in rigid diaphragm models. As indicated in Figure 11, roof displacement of model $4 \mathrm{SEW} 30 \% \mathrm{O}$ is virtually identical to that of model $4 \mathrm{SEW} 15 \% \mathrm{O} 1$ with opening located near the shear walls; the former, however, has two times the opening of the latter. Moreover, model $4 \mathrm{SEW} 15 \% \mathrm{O} 2$ with opening situated in the middle of plan of the building has identical roof displacement to that of model 4SEWNO (model without opening). Indeed, in addition to the size of opening, its location in building plan has enormous effect on response of building. As mentioned before, it is concluded that diaphragm opening has greater influence when it is located near shear walls.

As shown in Figure 11(b), enlargement in opening increases lateral displacement; nevertheless, Figure 11(a) opposes this fact by showing that model 4SEW $30 \% \mathrm{O}$ has lower displacement than model 4SEWNO when diaphragm is assumed rigid. Even though most of the rigid models have similar roof displacements, an inaccuracy occurs in response of model 4SEW $30 \% \mathrm{O}$ with rigid diaphragm. This miscalculation is because of rigid diaphragm assumption.

Diaphragm opening increases building lateral displacement and diaphragm in-plane deformation. Figure 12 shows roof displacement in models 4SEWNO and 4 SEW $30 \% \mathrm{O}$. Middle frame displacements are 


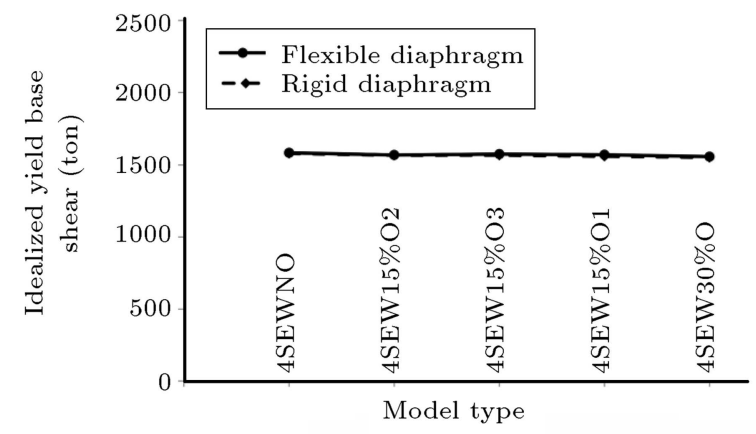

(a)

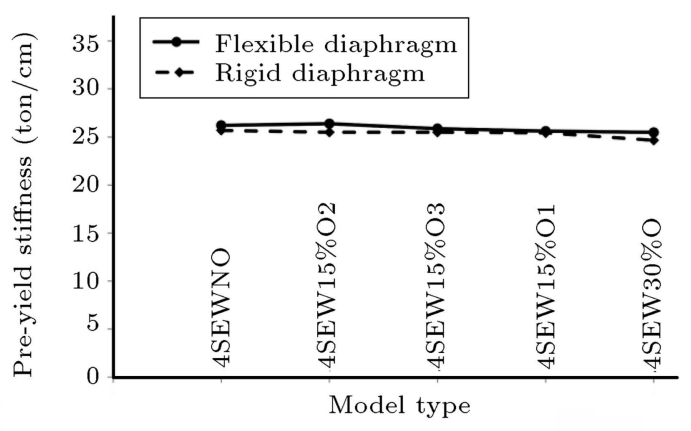

(b)

Figure 11. Maximum roof displacement with and without rigid diaphragm assumption: (a) Idealized yield base shear; and (b) post-yield stiffness.

Table 5. Maximum lateral displacement and in-plane deformation of diaphragm in both flexible and rigid models, and the error resulting from rigid diaphragm assumption.

\begin{tabular}{|c|c|c|c|c|c|c|c|c|c|c|c|c|c|c|c|c|}
\hline \multirow[b]{2}{*}{ Parameter } & \multirow[b]{2}{*}{ Story } & \multicolumn{3}{|c|}{ 4SEWNO } & \multicolumn{3}{|c|}{ 4SEW15\%O1 } & \multicolumn{3}{|c|}{ 4SEW15\%O2 } & \multicolumn{3}{|c|}{ 4SEW15\%O3 } & \multicolumn{3}{|c|}{ 4SEW30\%O } \\
\hline & & Flex. & Rigid & $\begin{array}{c}\text { Error } \\
\%\end{array}$ & Flex. & Rigid & $\begin{array}{c}\text { Error } \\
\%\end{array}$ & Flex. & Rigid & $\begin{array}{c}\text { Error } \\
\%\end{array}$ & Flex. & Rigid & $\begin{array}{c}\text { Error } \\
\%\end{array}$ & Flex. & Rigid & $\begin{array}{c}\text { Error } \\
\%\end{array}$ \\
\hline \multirow{4}{*}{$\begin{array}{c}\text { Maximum } \\
\text { lateral } \\
\text { displacement }\end{array}$} & 4 & 4.2 & 3 & 27.2 & 4.6 & 2.8 & 39.6 & 4.2 & 2.9 & 31 & 4.5 & 2.9 & 35.8 & 4.6 & 2.6 & 42.9 \\
\hline & 3 & 3.3 & 2.2 & 31.8 & 3.7 & 2.1 & 44.3 & 3.2 & 2.1 & 33.1 & 3.4 & 2.1 & 38.2 & 3.6 & 1.9 & 47.1 \\
\hline & 2 & 2 & 1.4 & 32.7 & 2.2 & 1.3 & 43.5 & 2.1 & 1.3 & 37 & 2.2 & 1.3 & 41.9 & 2.3 & 1.2 & 49.2 \\
\hline & 1 & 0.9 & 0.5 & 42.4 & 1.1 & 0.5 & 52.8 & 1 & 0.5 & 47.2 & 1 & 0.5 & 50.9 & 1 & 0.5 & 54.3 \\
\hline Maximum & 4 & 1.11 & 0 & - & 1.77 & 0 & - & 1.14 & 0 & - & 1.37 & 0 & - & 1.94 & 0 & - \\
\hline in-plane & 3 & 1 & 0 & - & 1.6 & 0 & - & 1.17 & 0 & - & 1.38 & 0 & - & 1.74 & 0 & - \\
\hline deformation & 2 & 0.89 & 0 & - & 1.19 & 0 & - & 1.04 & 0 & - & 1.16 & 0 & - & 1.22 & 0 & - \\
\hline of diaphragm & 1 & 0.6 & 0 & - & 0.7 & 0 & - & 0.58 & 0 & - & 0.62 & 0 & - & 0.64 & 0 & - \\
\hline
\end{tabular}

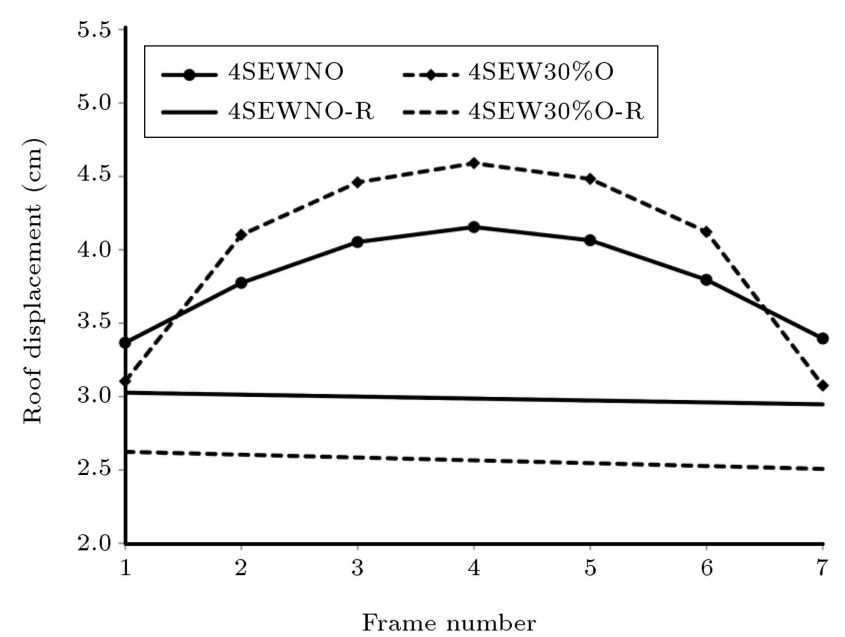

Figure 12. Maximum roof displacement in models 4SEWNO and 4SEW30\%O with and without rigid diaphragm assumptions.

$0.03 \mathrm{~m}$ and $0.026 \mathrm{~m}$, respectively, in models 4 SEWNO and 4 SEW $30 \% \mathrm{O}$ with rigid diaphragm, but they are $0.042 \mathrm{~m}$ and $0.046 \mathrm{~m}$ in models with flexible diaphragm. The error resulting from negligence is $27 \%$ in the model without opening and $43 \%$ in the model with thirty percent opening.

Diaphragm in-plane deformation is greater in roof diaphragm than other stories, and it is raised by expansion of opening. Table 5 gives maximum lateral displacement and maximum in-plane deformation of diaphragm in all stories of all models and indicate the error in computing these parameters due to diaphragm in-plane flexibility negligence.

\section{Conclusion}

Rigid diaphragm assumption is conventional in analysis and design of buildings. However, this hypothesis is not valid in such cases as narrow and long buildings, and it becomes worse if there are huge openings in diaphragm because of architectural purpose or stairs, to name but two. By increase in diaphragm opening, in-plane flexibility of floor diaphragm will increase, which causes high errors in seismic response of building and pushover results in the situation of rigid diaphragm assumption; for example, pre-yield stiffness is assessed in model 4SEW $30 \% \mathrm{O}$ by $58.6 \%$ of error. Additionally, besides the largeness of opening, its location has enormous influence on response of building; indeed, openings near the shear walls have stronger effect and lead to more in-plane flexibility of diaphragm. For instance, although models 4SEW15\%O1 and 4SEW15\%O2 have equal openings, analysis of the former model, in which opening is located near the shear wall, assessed preyield stiffness with $53.2 \%$ of error and analysis of the 
latter one, in which opening is situated in the farthest location from shear walls, estimated pre-yield stiffness with $33.6 \%$ of error. Thus, it would be better off avoiding opening near the shear walls; if not, the inplane flexibility of diaphragm has not to be overlooked even if the plan aspect ratio of building is 3 . In addition, it is concluded that in-plane flexibility of diaphragm has nothing to do with post-yield parameters of pushover curve, such as idealized yield base shear and post-yield stiffness, while it affects such pre-yield parameters as idealized yield displacement and preyield stiffness.

\section{References}

1. Lee, H.J. and Kuchma, D.A. "Seismic response of parking structures with precast concrete diaphragms", PCI Journal, 53(2), pp. 71-94 (2008).

2. Fleischman, R.B., Sause, R., Pessiki, S. and Rhodes, A.B. "Seismic behavior of precast parking structure diaphragms", PCI Journal, 43(1), pp. 38-53 (1998).

3. Fleischman, R.B., Restrepo, J.I., Naito, C.J., Sause, R., Zhang, D. and Schoettler, M., "Integrated analytical and experimental research to develop a new seismic design methodology for precast concrete diaphragms", Journal of Structural Engineering, 139(7), pp. 11921204 (2013).

4. ASCE, Minimum Design Loads for Buildings and Other Structures: ASCE Standard, 7-10. American Society of Civil Engineers (2010).

5. Moon, S.-K. and Lee, D.-G. "Effects of inplane floor slab flexibility on the seismic behaviour of building structures", Engineering Structures, 16(2), pp. 129144 (1994).

6. Kunnath, S., Panahshahi, N. and Reinhorn, A. "Seismic response of RC buildings with inelastic floor diaphragms", Journal of Structural Engineering, 117(4), pp. 1218-1237 (1991).

7. Doudoumis, I.N. and Athanatopoulou, A.M. "Code provisions and analytical modelling for the in-plane flexibility of floor diaphragms in building structures", Journal of Earthquake Engineering, 5(4), pp. 565-594 (2001).

8. Moeini, M. and Rafezy, B. "Investigation into the floor diaphragms flexibility in reinforced concrete structures and code provision", Global Journal of Research Engineering, 11(1) (2011).

9. Moeini, M., Rafezy, B. and Howson, W. "Investigation into the floor diaphragm flexibility in rectangular reinforced concrete buildings and error formula", 14 th World Conference on Earthquake Engineering, Beijing, China (2008).

10. Al Harash, M., Rathore, A. and Panahshahi, N. "Inelastic seismic response of rectangular RC buildings with plan aspect ratio of 3: 1 with floor diaphragm openings", in Structures Congress 2010, ASCE (2010).
11. Al Harash, M.T., Panahshahi, N. and Truman, K.Z. "Inelastic seismic response of reinforced concrete buildings with floor diaphragm openings", 14th World Conference on Earthquake Engineering, Beijing, China (2008).

12. ACI318-99, Building Code Requeriments for Structural Concrete (ACI 318-99) and Commentary (ACI 318R99) (1999).

13. UBC, Uniform Building Code, International Conference of Building Officials, Structural Engineering Provisions, Whittier, California (1997).

14. Masoomi, H. Influence of Floor Diaphragm on Seismic Response of RC Structures, in Civil Engineering, Sharif University of Technology, (2013).

15. Deierlein, G.G., Reinhorn, A.M. and Willford, M.R. "Nonlinear structural analysis for seismic design", NEHRP Seismic Design Technical Brief No. 4 (2010).

16. Kunnath, S.K., Reinhorn, A.M. and Park, Y.J. "Analytical modeling of inelastic seismic response of $\mathrm{R} / \mathrm{C}$ structures", Journal of Structural Engineering, 116(4), pp. 996-1017 (1990).

17. Spacone, E., Filippou, F.C. and Taucer, F.F. "Fibre beam-column model for non-linear analysis of R/C frames: Part I. Formulation", Earthquake Engineering and Structural Dynamics, 25(7), pp. 711-726 (1996).

18. Ibarra, L.F., Medina, R.A. and Krawinkler, H. "Hysteretic models that incorporate strength and stiffness deterioration", Earthquake Engineering \& Structural Dynamics, 34(12), pp. 1489-1511 (2005).

19. Heintz, J.A. "FEMA P-440A, Effects of strength and stiffness degradation on the seismic response of structural systems", in Improving the Seismic Performance of Existing Buildings and Other Structures, ASCE (2009).

20. PERFORM 3D, User Guide v4, Non-linear Analysis and Performance Assessment for $3 D$ Structures, Computers and Structures, Inc., Berkeley, CA. (2006).

21. FEMA, P., Commentary for the Seismic Rehabilitation of Buildings., FEMA-356, Federal Emergency Management Agency, Washington, DC, (2000).

22. Lee, H.-S., Lee, J.-J. and Jung, D.-W. "Analytical simulation of shake-table responses of a torsionallyeccentric piloti-type high-rise RC building model", 14 th World Conference on Earthquake Engineering, Beijing, China (2008).

23. El-Tawil, S. and Deierlein, G.G. "Nonlinear analysis of mixed steel-concrete frames. II: Implementation and verification", Journal of Structural Engineering, 127(6), pp. 656-665 (2001).

24. Mander, J.B., Priestley, M.J. and Park, R. "Theoretical stress-strain model for confined concrete", Journal of Structural Engineering, 114(8), pp. 18041826 (1988).

25. MacKay-Lyons, R. Performance-Based Design of $R C$ 
Coupled Wall High-Rise Buildings with Viscoelastic Coupling Dampers, University of Toronto (2013).

26. Ghodsi, T. and Ruiz, J.A.F. "Pacific earthquake engineering research/seismic safety commission tall building design case study 2", The Structural Design of Tall and Special Buildings, 19(1-2), pp. 197-256 (2010).

27. Canbolat, B.B. and Wight, J.K. "Experimental investigation on seismic behavior of eccentric reinforced concrete beam-column-slab connections", ACI Structural Journal, 105(2), pp. 154-162 (2008).

28. Burak, B., Seismic Behavior of Eccentric Reinforced Concrete Beam-Column-Slab Connections, University of Michigan (2005).

29. Choudhary, N. and Wadia, M. "Pushover analysis of RC frame building with shear wall", Journal of Mechanical and Civil Engineering, 11(2), pp. 09-13 (2014).

30. Federal Emergency Management Agency (FEMA) "Quantification of Building Seismic Performance Factors", FEMA-P695, Washington, DC. (2009).

\section{Biographies}

Ali Reza Khaloo received his PhD degree in Structural Engineering, in 1986, from North Carolina State University. He is currently professor in the Department of Civil Engineering at Sharif University of Technology, Tehran, Iran. His research interests include topics related to structural engineering, reinforced concrete structures, concrete composite materials, materials of construction, and earthquake engineering.

Hassan Masoomi received his MSc in Structural Engineering from Sharif University of Technology in Tehran, Iran, in 2013. He also obtained his BSc degree in Civil and Environmental Engineering from Iran University of Science and Technology (IUST) in Tehran, Iran, in 2011. His research interests include nonlinear analysis of structures, performance-based earthquake engineering, and structural reliability and risk analysis.

Saeed Nozhati graduated with MSc in Earthquake Engineering from Sharif University of Technology in Tehran, Iran, in 2013. He also obtained his BSc degree in Civil and Environmental Engineering from Iran University of Science and Technology (IUST) in Tehran, Iran, in 2011. His research interests include repair and rehabilitation of structures, performancebased earthquake engineering, and structural reliability.

Mohamad Mohamadi Dehcheshmeh is a $\mathrm{PhD}$ student at Iran University of Science and Technology (IUST) in Tehran, Iran. He received his MSc and BSc degrees both from IUST in Civil Engineering. His research interests include nonlinear analysis of structures and seismic analysis and design. 